\title{
Reagin-Mediated Asthma in Rhesus Monkeys and Relation to Bronchial Cell Histamine Release
} and Airway Reactivity to Carbocholine

\author{
Roy Patterson, Kathleen E. Harris, Irena M. Suszko, and \\ MARY ROBERTS \\ From the Section of Allergy-Immunology, Department of Medicine, \\ Northwestern University Medical School, Chicago, Illinois 60611
}

\begin{abstract}
A B S T R A C T Rhesus monkeys with persistent immediate-type cutaneous and respiratory responses (RR) to ascaris antigen (AA) were compared with rhesus monkeys with skin reactivity and no respiratory responses, and animals with no skin reactivity and no respiratory responses to inhaled antigen (NR). The $R R$ group could not be distinguished from the nonresponding (NR) group by the cutaneous skin test titers, serum, or respiratory secretion $\operatorname{IgE}$ concentration. Leukocyte histamine $(\mathrm{H})$ release due to anti- $\operatorname{IgE}$ was similar with peripheral blood leukocytes and bronchial lumen mast cells (MC) from $R R$ and NR animals. The $R R$ group of animals could be distinguished from the NR group by their degree of sensitivity to inhaled carbocholine and $\mathrm{H}$ release from respiratory $\mathrm{MC}$ exposed to $\mathrm{AA}$. The $\mathrm{RR}$ group demonstrates consistent, persistent respiratory responses suitable for immunologic, pharmacologic, and physiologic studies. Finally, it was found that the $\operatorname{IgE}$ concentration in respiratory secretions of rhesus monkeys was comparatively higher than in serum, evidence for $\operatorname{IgE}$ as a secretory $\operatorname{Ig}$ in the respiratory tract of this species.
\end{abstract}

\section{INTRODUCTION}

For several years we have studied animals with immediate-type airway responses to inhaled antigens in attempts to provide a model of human asthma suitable for immunologic, pharmacologic, and physiologic studies. The features of such a model that seemed desirable included the following: The immunologically mediated hypersensitivity should be due to reaginic antibody analogous to human $\operatorname{IgE}$; spontaneous, i.e., due to ex-

Received for publication 22 September 1975 and in revised form 3 November 1975. posure to antigens in the environment rather than a result of laboratory immunization procedures; and of long duration, so that the reactivity was similar to the human disease state and so that the same animal could be studied in repetitive experiments. The animals should be sufficiently large so that pulmonary function studies, bronchial lavage, and other studies could be done with ease and without loss of the animal. Canine and primate models fulfilling these criteria were developed and the characteristics of the responses recently reviewed (1). The canine model had the advantage of availability but usefulness was limited by the marked variability of each animal's response in individual experiments to antigen challenge, even under experimental conditions controlled as carefully as possible. The monkey model, with Macaca mulatta, appeared significantly superior to the canine system in that the airway responses were more consistent in degree of reaction and occurred in primates; thus, they more likely simulate human responses. The major limitation of the rhesus model, which we reported previously, was that the availability of animals with the type of respiratory reactivity required appeared sufficiently limited to inhibit significantly the potential usefulness of this system (1). We now report the method of establishment of a colony of rhesus monkeys that fulfill the criteria described above, the status of these animals over observation ranging from 1 to $3 \mathrm{yr}$, and some recent observations comparing animals with persistent airway responses with the nonreactive controls.

We propose that the rhesus monkeys with the respiratory responses described in these experiments constitute the most appropriate model of human asthma currently available. Further, use of the animals as described for these experiments carefully conserves a spe- 
cies that may become increasingly fewer and less available.

\section{METHODS}

Animals. Animals are young adult male and female $M$. mulata, obtained from Primate Imports Corp., Port Washington, N. Y. Initially, monkeys received for research at this medical center were screened for cutaneous reactivity to ascaris antigen (AA). ${ }^{1}$ Those animals with marked cutaneous reactivity (positive at a $10^{-3}$ dilution) to ascaris challenge were retained for further study. Subsequently, a cutaneous screening service has been conducted by Primate Imports, Inc. This service has included skin-testing animals to the purified AA and supplying only those animals with cutaneous reactivity, with a positive cutaneous response to challenge with a $10^{-3}$ dilution of antigen. All animals are considered free of parasitic infestations because all have received treatment with at least two separate courses of thiabendazole. Each animal is housed individually, with standard cage cleaning with wash water at $180^{\circ} \mathrm{C}$, limiting possibilities of cross-contamination with parasitic infestations. Fecal examination of selected animals have revealed no evidence of ova or parasites.

Antigens and antisera. AA is a sequential Sephadex (Pharmacia Fine Chemicals, Inc., Piscataway, N. J.) G50 and 75 column fraction of Ascaris suum extract prepared by the method of Hogarth-Scott (2). Standardization of each preparation of AA was done both by determination of protein as estimated by optical density at $280 \mathrm{~nm}$ (Beckman DU spectrophotometer; Beckman Instruments, Fullerton, Calif.) and cutaneous titration in AA-sensitive animals (3). The preparation of AA in current use contains 0.8 $\mathrm{mg}$ protein $/ \mathrm{ml}$ and is stored at $4^{\circ} \mathrm{C}$ in phosphate-buffered $0.15 \mathrm{M} \mathrm{NaCl}, \mathrm{pH} 7.35$ (PBS). Rabbit anti-human IgE was prepared against the $\mathrm{Fc}$ fragment of $\mathrm{IgE}$ myeloma P.S. Such anti-human IgE has been shown to cross-react with rhesus $\operatorname{IgE}(4)$. The anti-IgE used in these studies bound $0.828 \mathrm{mg}{ }^{125} \mathrm{I}-\mathrm{IgE} / \mathrm{ml}$.

Cutaneous testing. Animals were anesthetized with pentobarbital and received $2.5 \mathrm{ml}$ of $0.5 \%$ Evans' blue dye. Intracutaneous tests were performed by injection of 0.1 $\mathrm{ml}$ of serial 10-fold dilutions of AA in PBS. The cutaneous titer was recorded as the dilution of antigen producing the last definitive positive bluing reaction, as compared with the control site injected with PBS $(3,5)$.

Pharmacologic agents. Carbocholine (Car) and histamine $(\mathrm{H})$ were obtained from Sigma Chemical Co., St. Louis, Mo. Varying concentrations were dissolved in PBS and delivered to the respiratory tract as described below.

Aerosol antigen challenge and determination of pulmonary function parameters. Animals received aerosol challenges no more frequently than every $2 \mathrm{wk}$. For an aerosol antigen experiment, the rhesus monkeys were anesthetized with pentobarbital, and an endotracheal tube and an esophageal catheter were inserted. After a period of observation, the animals receive a control aerosol challenge with PBS. Base-line pulmonary function studies were obtained subsequent to this challenge, and next the AA aerosol challenge

${ }^{2}$ Abbreviations used in this paper: AA, ascaris antigen; Car, carbocholine; $\mathrm{H}$, histamine; NR, negative respiratory responder; $\mathrm{PBS}$, phosphate-buffered saline $(0.15 \mathrm{M} \mathrm{NaCl}$, $\mathrm{pH} 7.35)$; $\mathrm{PBL}$, peripheral blood leukocytes; RC, respiratory cells; $R R$, positive respiratory responder; $R S$, respiratory secretions; $\mathrm{S}$, serum. was administered. The AA challenge was delivered in a standard manner (3), with an in-line nebulizer in a Bird Mark VII (Bird Corp., Ltd., Richmond, Calif.) respirator with all settings controlling respirations constant for each experiment in each animal. The animal received a standard number of inhalations of the AA (currently 15 inhalations of a 1:5 dilution of standard AA) and changes in pulmonary function subsequent to this challenge were recorded. The methodology for recording changes in pulmonary function has been described in detail recently (6). Recordings of the following parameters of respiration are made: breathing frequency, peak expiratory flow rate, tidal volume, ratio of expiratory to inspiratory time, pulmonary resistance, and dynamic compliance. In selected experiments, arterial $\mathrm{Po}_{2}$ muscle $\mathrm{Po}_{2}$, or both are recorded by indwelling electrodes with a disposable in vivo oxygen catheter attached to a multipurpose oxygen analyzer (International Biophysics Corp., Irvine, Calif.) (7). In a large series of experiments, considerable variations were observed in the respiratory function parameters of different animals (6). Because of this, the most useful experimental system for analysis of the AA response was found to be the comparison of post-challenge results with those obtained during the control period after the PBS challenge, with expression of the results as percent change in pulmonary function from the base-line control period.

Respiratory secretions (RS) and cells. Rhesus monkeys were anesthetized and an endotracheal tube was inserted A $1.5-\mathrm{mm}$ catheter was passed through the endotracheal tube. $50 \mathrm{ml}$ of lactated Ringer's solution in aliquots of 10 $\mathrm{ml}$ were used to lavage the bronchi with intermittent aspiration of the lavage fluid. The recovered fluid, between 50 $75 \%$ of the volume of the lactated Ringer's introduced, was centrifuged and the cells were used for mediator release studies and the supernate was used for the quantitation of selected proteins.

Estimation of rhesus $\operatorname{serum}(S)$ and $R S$ proteins. The RS was concentrated by means of a diaflo ultrafiltration membrane XM 50 with a 10 PA Propellent Cell (Amicon Corp., Lexington, Mass.). The concentrations of albumin and IgG were estimated by means of radial immunodiffusion plates prepared for quantitation of human serum albumin and IgG (Behring Diagnostics, American Hoechst Corp., Sommerville, N. J.). IgE concentration was determined by the double-antibody radioimmunoassay of Gleich et al. (8). This inhibition assay, developed for measurement of human $\mathrm{IgE}$, expresses $\mathrm{IgE}$ as units and $1 \mathrm{U}$ approximates $2.4 \mathrm{ng}$ of IgE. The use of these assays for human serum proteins for quantitative estimation of the rhesus monkey serum proteins is based on the cross-reactivity of antiserum against human serum proteins with the analogous serum proteins from other primates. For example, the cross-reactivity of monkey IgE with antiserum against human $\operatorname{IgE}$ was established by Ishizaka and Ishizaka (9). In this laboratory, experiments conducted with monkey serum albumin (a Sephadex G200 peak III preparation of rhesus serum), monkey IgG (a diethylaminoethyl peak I preparation of rhesus serum) (DEAE reference), and $\mathrm{IgE}$ (with whole monkey reaginic serum) indicated at least $70 \%$ cross-reactivity between these rhesus monkey serum proteins and the analogous human serum proteins with the antiserum currently in use against human serum proteins. In these experiments, the concentrations of rhesus albumin, IgG, and $\mathrm{IgE}$ are compared only with the concentrations of these proteins from different animals or different body fluids of the same animals. The results are expressed as milligrams per milliliter for albumin and IgG and units per milliliter for IgE, with the clear 
TABLE I

Criteria for a Positive Respiratory Response to AA Challenge in Ascaris-Sensitive Rhesus Monkeys

1. The acute change in pulmonary function (PF) must occur within $5 \mathrm{~min}$, with the peak abnormalities at 2 or $5 \mathrm{~min}$ after completion of antigen challenge.

2. The change of PF parameters must be in the expected direction: an increased $\mathrm{F}, \mathrm{PR}$, and $\mathrm{E} / \mathrm{I}$, and a decreased PEFR, TV, and C. The parameters must remain in this direction for at least the 2- and 5-min recordings before or after the peak change.

3. The minimum percent change from base line must be at least $\mathrm{f},+20 \%$; $\mathrm{PR},+15 \% ; \mathrm{E} / \mathrm{I},+30 \%$; PEFR, $-15 \%$; $\mathrm{TV},-15 \% \mathrm{C},-45 \%$.

4. Four of six PF parameters must meet the above criteria

Abbreviations used in this table: $\mathrm{C}$, dynamic compliance; E/I, ratio of expiratory to inspiratory time; $f$, breathing frequency; PEFR, peak, expiratory flow rate; $\mathrm{PF}$, pulmonary function; $\mathrm{PR}$, pulmonary resistance; $\mathrm{TV}$, tidal volume.

reservation in the Results section that this expression is for comparing relative concentrations in serum and respiratory secretions of animals of the same species.

Peripheral blood leukocyte $(P B L)$ and respiratory cell $(R C)$ histamine release. These studies were done as previously described (10). Briefly, PBL and RC were obtained at the same time from the same animal. The $\mathrm{RC}$ were the cells obtained at time of bronchial lavage. For PBL, a sample of $25 \mathrm{~cm}^{3}$ heparinized blood was mixed with a $5 \%$ high molecular weight dextran solution. After sedimentation of red blood cells, the PBL layer was centrifuged and

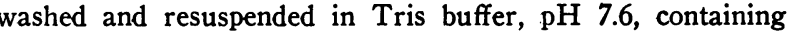
$\mathrm{Ca}^{++}$and $\mathrm{Mg}^{++}$(Tris-Ca-Mg). The $\mathrm{RC}$, obtained in lactated Ringer's, were centrifuged, washed, and reconstituted in Tris-Ca-Mg. Release of $\mathrm{H}$ from both PBL and RC, due to either anti-IgE or AA, was performed in Tris-Ca- $\mathrm{Mg}$ buffer. When the effect of $\mathrm{D}_{2} \mathrm{O}$ on $\mathrm{H}$ release was studied then Tris-Ca-Mg buffer was prepared as $60 \% \quad \mathrm{H}_{2} \mathrm{O}$ and $40 \% \mathrm{D}_{2} \mathrm{O}$, as previously described $(4,10)$.

Determination of histamine $(H)$. $\mathbf{H}$ was extracted from PBL and RC samples by the standard methods (11), and the content of $\mathrm{H}$ was determined with an Aminco-Bowman spectrophotofluorometer (American Instrument Co., Silver Spring, Md.).

\section{RESULTS}

Current status of the monkey colony. The total population of the monkey colony is 12 animals. 10 of these animals were selected for the colony because of the presence of positive cutaneous reactivity to dilutions of $10^{-8}$ or greater of AA. Two animals with negative cutaneous reactivity to undiluted AA were retained as subjects with negative skin reactivity. The respiratory reactivity of the reactive animals is as follows: Six animals are classified as consistent respiratory reactors (RR) to aerosol challenge. Current criteria for a positive respiratory response are summarized in Table $\mathrm{I}$ and an example of a positive response is shown in Fig. 1.
$R R$ animals have persistent respiratory responses, arbitrarily defined as at least six consecutively positive respiratory responses to aerosol challenge over a period of $12 \mathrm{mo}$. Five monkeys are classified as negative respiratory responders (NR). These animals have persistently negative respiratory responses for at least three consecutive experiments over $3 \mathrm{mo}$, with the exception of one animal with negative skin reactivity, in which one negative aerosol challenge was considered sufficient. One of the animals with cutaneous reactivity to a $10^{-4}$ dilution of AA was classified as an erratic respiratory responder. This animal had either positive or negative responses. Five animals in each group were selected for detailed analysis of possible differences between animals classified as RR and NR.

Some characteristics of animals with and without consistent respiratory responses to $A A$. Table II summarizes the current status of 10 of the 12 animals in the colony. The monkey with erratic responses described above and one animal observed for less than $1 \mathrm{yr}$ were not included. Eight animals were selected for cutaneous reactivity to AA. The degree of cutaneous reactivity to AA in the RR group is somewhat greater, as determined by the endpoint titration (Table II), but this technique does not clearly separate the RR group from the NR group, since endpoint titers of $10^{-3}$ appear in both groups. No statement can be made about sex differences in this series. It it apparent that animals with consistently positive responses of long duration can be ob-

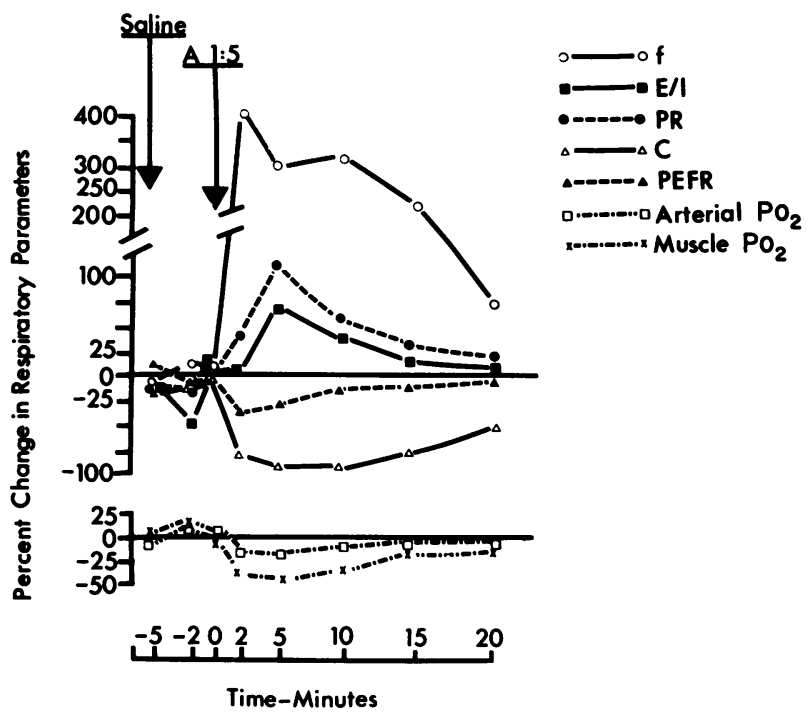

Figure 1 A respiratory response in a reactive rhesus monkey induced by AA aerosol challenge after a control aerosol challenge with $0.15 \mathrm{M} \mathrm{NaCl}$. $\mathrm{f}$, breathing frequency; $\mathrm{E} / \mathrm{I}$, ratio of expiratory time to inspiratory time; $\mathrm{PR}$, pulmonary resistance; C, dynamic compliance; PEFR, peak expiratory flow rate. 
TABLE II

Some Characteristics of Two Groups of Monkeys with Cutaneous Reactivity to AA

\begin{tabular}{|c|c|c|c|c|c|c|}
\hline $\begin{array}{l}\text { Monkey } \\
\text { number }\end{array}$ & $\begin{array}{l}\text { Classification } \\
\text { of monkey }\end{array}$ & Sex & $\begin{array}{l}\text { Cutaneous } \\
\text { reactivity* }\end{array}$ & $\begin{array}{l}\text { Duration of } \\
\text { observation }\end{array}$ & $\begin{array}{l}\text { Reproducibility: } \\
\text { number of } \\
\text { respiratory } \\
\text { responses } \\
\text { - total number } \\
\text { of challenges }\end{array}$ & $\begin{array}{l}\text { Consistency: number } \\
\text { of consecutive } \\
\text { positive responses }\end{array}$ \\
\hline & & & & $y r$ & & \\
\hline 1 & $\mathrm{RR}$ & $\mathbf{M}$ & $10^{-4}$ & $2 \frac{1}{4}$ & $17 / 19$ & 8 \\
\hline 2 & $\mathrm{RR}$ & $F$ & $10^{-3}$ & $2 \frac{1}{4}$ & $14 / 14$ & 14 \\
\hline 3 & $\mathrm{RR}$ & $\mathbf{M}$ & $10^{-5}$ & $2 \frac{1}{4}$ & $14 / 15$ & 12 \\
\hline 4 & $\mathrm{RR}$ & $\mathbf{M}$ & $10^{-8}$ & $1 \frac{1}{2}$ & $9 / 9$ & 9 \\
\hline 5 & $\mathrm{RR}$ & $\mathrm{F}$ & $10^{-4}$ & $2 \frac{1}{4}$ & $10 / 12$ & $\begin{array}{l}\text { Final } 10 \text { experiments } \\
\text { positive }\end{array}$ \\
\hline 6 & NR & $\mathrm{F}$ & $10^{-3}$ & 2 & $1 / 10$ & \\
\hline 7 & NR & $\mathrm{F}$ & Negative & $3 \frac{3}{4}$ & $0 / 5$ & \\
\hline 8 & NR & $\mathbf{M}$ & $10^{-3}$ & 3 & $0 / 3$ & \\
\hline 9 & NR & $\mathbf{M}$ & $10^{-3}$ & $1 \frac{1}{4}$ & $2 / 6$ & $\begin{array}{l}\text { Final } 4 \text { experiments } \\
\text { negative }\end{array}$ \\
\hline 10 & NR & M & Negative & $2 \frac{1}{4}$ & $0 / 1$ & \\
\hline
\end{tabular}

Half the group had repeated positive respiratory responses to aerosol challenge with AA. Abbreviations: RR, respiratory responder to AA aerosol challenge; NR, nonrespiratory responder to AA aerosol challenge; $M$, male; $F$, female.

* Highest serial 10-fold dilution of AA resulting in a positive reaction after cutaneous testing.

tained. Animal 5 (Table II) is the only rhesus monkey we have observed that developed persistent positive respiratory responses to AA after two initial negative aerosol challenges. All other animals have remained negative in spite of repeated aerosol challenges. The results in Table II indicate that monkeys with prolonged respiratory responsiveness to aerosolized antigen may be maintained for considerable periods of time. This respiratory reactivity to $\mathrm{AA}$ is maintained in the apparent absence of parasitic infestation. Intervals be-

TABLE III

Quantitation of IgE, IgG, and Albumin in Serum and Bronchial Specimens from Two Groups of Rhesus Monkeys (See Table II) and Comparison of Combined Protein Ratios

\begin{tabular}{|c|c|c|c|c|c|c|c|c|c|c|}
\hline \multirow[b]{2}{*}{ Animal } & \multicolumn{2}{|c|}{$\mathrm{IgE}^{*}$} & \multicolumn{2}{|c|}{ IgG* } & \multicolumn{2}{|c|}{ Alb* } & \multicolumn{2}{|c|}{$\begin{array}{c}\text { Ratio } \\
\text { IgE/Alb }\end{array}$} & \multicolumn{2}{|c|}{$\begin{array}{r}\text { Ratio\& } \\
\text { IgG/Alb }\end{array}$} \\
\hline & $\mathbf{S}$ & RS & $\mathbf{S}$ & RS & $\mathbf{S}$ & RS & $\mathbf{s}$ & RS & $\mathbf{S}$ & RS \\
\hline & \multicolumn{2}{|c|}{$U / m l$} & \multicolumn{2}{|c|}{$m g / m l$} & \multicolumn{2}{|c|}{$m g / m l$} & & & & \\
\hline \multirow[t]{2}{*}{1} & 34 & 9 & 18 & 0.16 & 48 & 1 & 0.70 & 9.0 & 0.38 & 0.16 \\
\hline & 35 & 20 & 17 & 0.48 & 57 & 2 & 0.61 & 10.0 & 0.30 & 0.24 \\
\hline 2 & 38 & 10 & 13 & 0.09 & 53 & 1 & 0.71 & 10.0 & 0.25 & 0.09 \\
\hline 3 & 35 & 23 & 25 & 1.1 & 51 & 2.1 & 0.68 & 10.9 & 0.49 & 0.52 \\
\hline 4 & 23 & 9 & 8.8 & 0.42 & 51 & 2.5 & 0.45 & 3.6 & 0.17 & 0.17 \\
\hline 5 & 36 & 10 & 14.5 & 0.27 & 58 & 2.8 & 0.62 & 3.6 & 0.25 & 0.10 \\
\hline Mean \pm SEM & $34 \pm 2.2$ & $14 \pm 2.6$ & $16 \pm 2.2$ & $0.42 \pm 0.14$ & $53 \pm 1.6$ & $1.9 \pm 0.3$ & $0.63 \pm 0.04$ & $7.9 \pm 1.4$ & $0.31 \pm 0.05$ & $0.21 \pm 0.07$ \\
\hline 6 & 18 & 14 & 14 & 0.14 & 54 & 2.1 & 0.33 & 6.7 & 0.26 & 0.07 \\
\hline \multirow[t]{4}{*}{7} & 27 & 7 & 16 & 0.14 & 65 & 1.1 & 0.40 & 6.4 & 0.25 & 0.13 \\
\hline & 34 & 9 & 12 & 0.18 & 44 & 1.3 & 0.78 & 6.9 & 0.27 & 0.14 \\
\hline & 29 & 16 & 16 & 0.20 & 53 & 2.8 & 0.55 & 5.7 & 0.30 & 0.07 \\
\hline & 28 & 6 & 18 & 0.14 & 51 & 1.8 & 0.55 & 3.3 & 0.35 & 0.08 \\
\hline 8 & 28 & 10 & 13.5 & 0.18 & 58 & 1.3 & 0.48 & 7.7 & 0.23 & 0.14 \\
\hline 9 & 38 & 9.5 & 17 & 0.3 & 51 & 2.1 & 0.70 & 4.4 & 0.33 & 0.14 \\
\hline 10 & 42 & 10 & 13.5 & 0.27 & 56 & 2.0 & 0.75 & 5.0 & 0.24 & 0.13 \\
\hline Mean \pm SEM & $30.5 \pm 3.3$ & $10.2 \pm 1.2$ & $15 \pm 0.7$ & $0.19 \pm 0.02$ & $54 \pm 2.2$ & $1.8 \pm 0.6$ & $0.57 \pm 0.06$ & $5.8 \pm 0.5$ & $0.28 \pm 0.014$ & $0.11 \pm 0.01$ \\
\hline
\end{tabular}

* Concentrations were determined by methods for measurement of analogous human serum proteins and expressed quantitatively for comparative purposes only (see Methods).

$\ddagger \mathrm{IgE}$ value $(\mathrm{U} / \mathrm{ml})$ per albumin value $(\mathrm{mg} / \mathrm{ml})$.

IgG value $(\mathrm{mg} / \mathrm{ml})$ per albumin value $(\mathrm{mg} / \mathrm{ml})$. 
tween AA experiments have been extended as long as 6 mo without loss of respiratory responses.

Evaluation of $S$ and $R S$ proteins. Relative concentrations of albumin, $\operatorname{IgE}$, and $\operatorname{IgG}$ in $\mathrm{S}$ and $\mathrm{RS}$ were compared in the RR and NR groups of monkeys to determine if differences in concentrations of these proteins, particularly $\operatorname{IgE}$, might distinguish the $\mathrm{RR}$ from the NR. The results (Table III) demonstrate no significant differences in the concentrations of these proteins in either $S$ or $R S$ between the RR and NR groups of monkeys. The results of Table III demonstrate that the $\mathrm{S}$ and $\mathrm{RS}$ ratios of $\mathrm{IgE} / \mathrm{Alb}$ and $\mathrm{IgG} / \mathrm{Alb}$ are relatively consistent when individual animals are compared and when samples are obtained repeatedly from the same animal. A definite difference is apparent when the ratios of $\mathrm{IgE} / \mathrm{Alb}$ and $\mathrm{IgG} / \mathrm{Alb}$ in $\mathrm{S}$ are compared with these ratios in RS (Table III and Fig. 2). The significantly higher $\mathrm{IgE} / \mathrm{Alb}$ ratio demonstrated in $\mathrm{RS}$ as compared with $\mathrm{S}$ indicates that the $\operatorname{IgE}$ is a secretory $\operatorname{Ig}$ in the lower (subglottic) respiratory tract in this species and that $\mathrm{IgG}$ is not.

$H$ release phenomena. The release of $\mathrm{H}$ from $\mathrm{PBL}$ and $\mathrm{RC}$ due to two immunologic stimuli (anti- $\operatorname{IgE}$ and AA) in the two groups of animals was compared to determine whether or not differences between the two groups could be demonstrated. The potentiating effect of $\mathrm{D}_{2} \mathrm{O}$ on the release of $\mathrm{H}$ was also studied. The results of $H$ release from $P B L$ and $R C$ due to anti- $\operatorname{IgE}$ are shown in Fig. 3. Significant $\mathrm{H}$ release (more than $15 \%$ ) occurred from PBL from every animal tested,

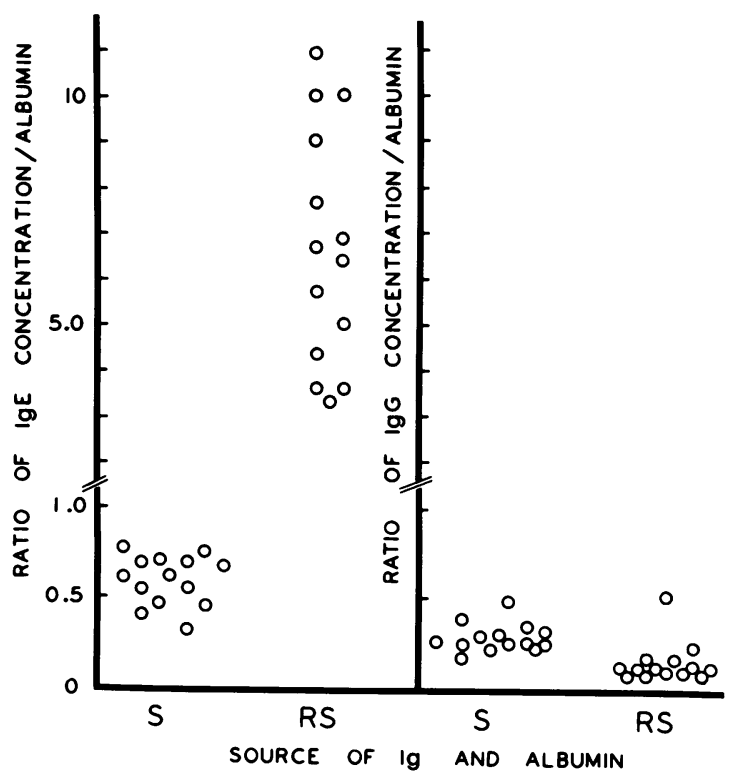

FIGURE 2 Ratios of IgE/albumin and IgG/albumin in serum (S) and respiratory secretions (RS) of the rhesus monkeys, calculated from results listed in Table II.

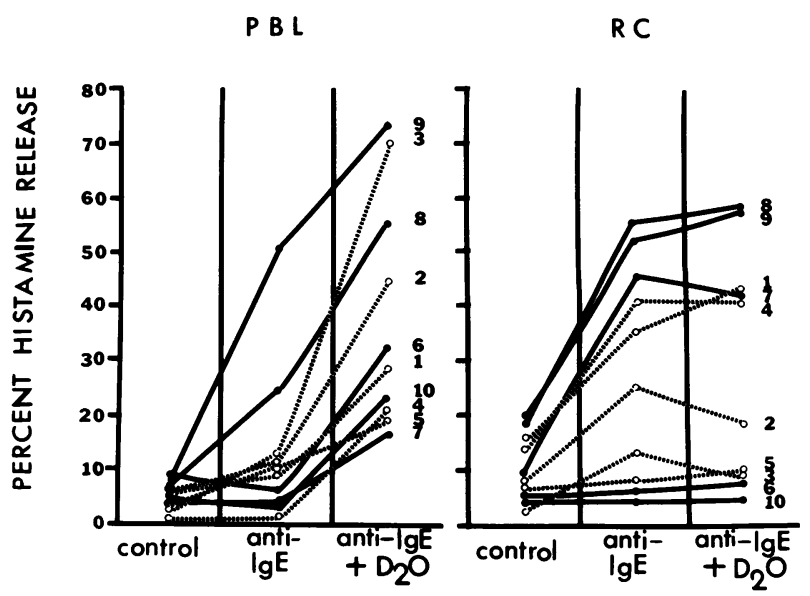

Figure 3 Histamine release from cells from two groups of rhesus monkeys after exposure to anti-IgE in the presence or absence of $40 \% \mathrm{D}_{2} \mathrm{O}$. Numbers refer to ascaris respiratory responders $(---)$ or nonresponders $(-)$, listed in Table II. Left, histamine release from peripheral blood leukocytes; right, histamine release from respiratory cells.

although $\mathrm{D}_{2} \mathrm{O}$ was necessary to demonstrate a significant release in most samples (Fig. 3). The potentiating effect of $\mathrm{D}_{2} \mathrm{O}$ on $\mathrm{H}$ release from $\mathrm{PBL}$ is evident. Significant $\mathrm{H}$ release from $\mathrm{RC}$ due to anti- $\mathrm{IgE}$ occurred with cells from all animals except two, and no significant potentiating effect of $\mathrm{D}_{2} \mathrm{O}$ is seen (Fig. 3). No difference in the degree of $\mathrm{H}$ release from either $\mathrm{PBL}$ or $\mathrm{RC}$ from the two groups of monkeys $R R$ and NR was observed in these studies with anti-IgE as the immunologic stimulus. The results of $\mathrm{H}$ release studies due to AA are shown in Fig. 4. Significant $\mathrm{H}$ release occurred from $\mathrm{PBL}$ with or without $\mathrm{D}_{2} \mathrm{O}$ in all but two experiments (Fig. 4). These two negative experiments used cells from the two animals with no skin reactivity to AA. The release of $\mathrm{H}$ from $\mathrm{PBL}$, when it occurred, was potentiated by $\mathrm{D}_{2} \mathrm{O}$. Except for these two animals with negative skin reactivity to $A A$, the $R R$ group could not be distinguished from the NR group by the degree of $\mathrm{H}$ release either with or without $\mathrm{D}_{2} \mathrm{O}$ (Fig. 4).

$\mathrm{H}$ release occurred from some $\mathrm{RC}$ after exposure to AA (Fig. 4). The release was less than that from PBL of the same animal (Fig. 4). Potentiation of $\mathrm{RC} \mathrm{H}$ release occurred with $\mathrm{D}_{2} \mathrm{O}$, but this potentiation is less than with PBL from the same animal. The $\mathrm{H}$ release studies show a difference between the RR and the NR, in that no evidence of $\mathrm{H}$ release due to $\mathrm{AA}$, either with or without $\mathrm{D}_{2} \mathrm{O}$, was demonstrated in the NR group, whether they were positive or negative skin reactors.

Responses of rhesus monkeys to carbocholine (Car). Previous studies demonstrated that aerosol challenge of a rhesus monkey with a sufficient concentration of Car resulted in an airway response similar to that observed 
after challenge with antigen (Fig. 1), prostaglandin $F_{2 \alpha}$, or $H$ (12). The $R R$ and NR groups of animals (Table II) were tested with 15 inhalations of increasing concentrations of Car $(0.1 \mathrm{mg}, 0.25,2.5$, and $10 \mathrm{mg} / \mathrm{ml}$ ). The concentration of Car that gave a definitive respiratory response was determined. An example of a recording of respiratory function of such an experiment is shown in Fig. 5. This demonstrates a positive respiratory response to a concentration of $2.5 \mathrm{mg}$ $\mathrm{Car} / \mathrm{ml}$. All animals in Table II were tested identically to determine the threshold concentration of Car giving a positive response. The criteria for a positive respiratory response to aerosolization of $\mathrm{Car}$ were those described above for determination of a positive respiratory response to antigen challenge (Table I). The lowest concentrations of Car to which animals in Table II reacted are shown in Table IV. These results show that the RR group can be distinguished from the NR by the degree of respiratory responsiveness to Car. This is most apparent at the concentration of $2.5 \mathrm{mg} / \mathrm{ml}$ under the conditions of these experiments.

\section{DISCUSSION}

The rhesus monkey colony described here demonstrates that a group of primates with immediate-type respiratory responses to a purified antigen has been obtained without great difficulty. The respiratory responsiveness of these animals is of long duration, is due to natural rather than experimental sensitization, is reproducible in repeated experiments, and is consistently positive (Table II). We believe that the characteristics of these primates, with consistent, persistent, reagin-mediated respiratory responsiveness to antigen inhalation present in only a part of a population of animals with immedi-
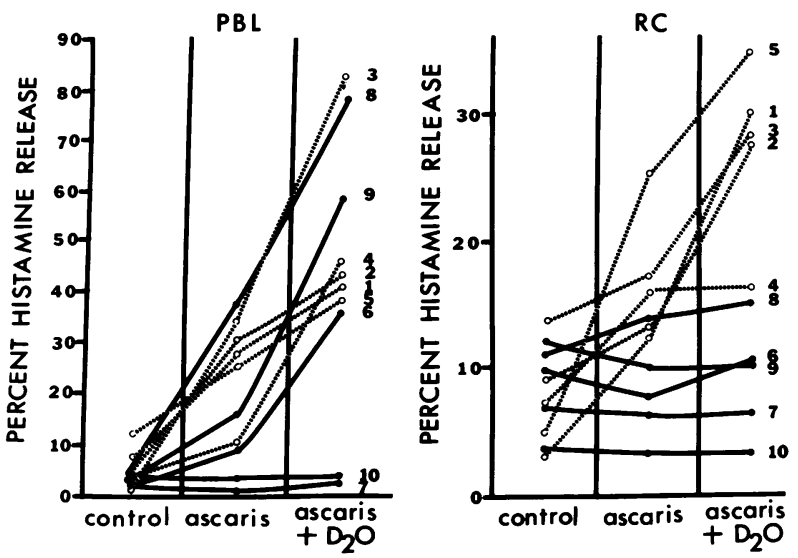

Figure 4 Histamine release from cells from two groups of rhesus monkeys after exposure to AA in the presence or absence of $40 \% \mathrm{D}_{2} \mathrm{O}$. Numbers refer to ascaris respiratory responders (- - -) or nonresponders $(-)$, listed in Table II. Left, histamine release from peripheral blood leukocytes; right, histamine release from respiratory cells.

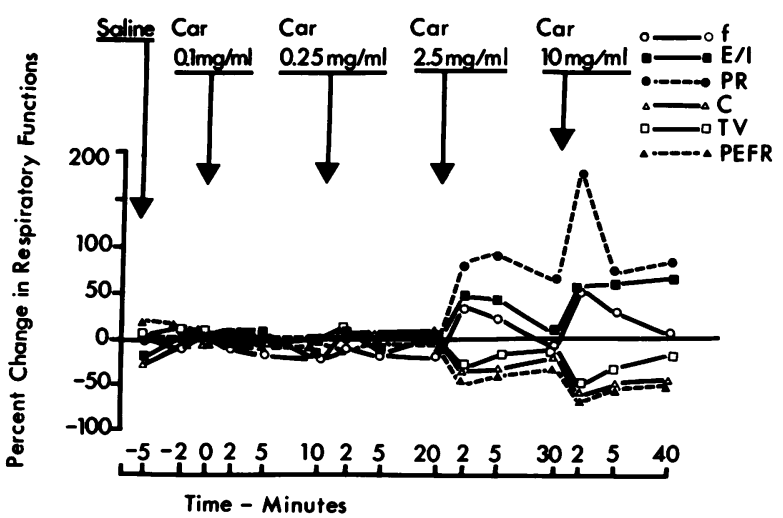

FIGURE 5 Pulmonary function parameters of a rhesus monkey challenged by aerosol with increasing concentrations of Car. $f$, breathing frequency, E/I, ratio of expiratory time to inspiratory time; $\mathrm{PR}$, pulmonary resistance; $\mathrm{C}$, dynamic compliance; TV, tidal volume; PEFR, peak expiratory flow rate.

ate-type skin reactivity, constitutes the closest analogue in animals to human extrinsic or reagin-mediated asthma. The availability of such animals provides a resource for study of a variety of immunologic and physiologic mechanisms. The types of experiments and information obtained from animals of this type are summarized in Table V. The animals compared and described in this study do not constitute the total population of animals used in the experiments resulting in information listed in Table $\mathrm{V}$.

The use of rhesus monkeys as described in these experiments constitutes what should be considered a conservational use of primates for laboratory research. The experiments listed for respiratory responders in Table II demonstrate the number of studies possible without loss of any animal in that group for a total time of $10 \frac{1}{2}$ monkey yr. The simultaneous use of these animals for the cell studies (Figs. 3 and 4 ) further demonstrates a way of conserving a species decreasing in availability because of excessive use of subhuman primates for fatal experiments.

The results of studies of the proteins obtained by bronchial lavage of monkeys in these studies are similar to those obtained by bronchial lavage of human lungs (13). In volunteer nonsmoking human subjects, the ratios of $\mathrm{IgG}$ to $\mathrm{Alb}$ were $0.12 \pm 0.02$ (mean $\pm \mathrm{SEM}$ of combined ratios) in bronchial fluid and $0.23 \pm 0.02$ in serum (13). These ratios were of similar magnitude in the bronchial fluid and serum of the rhesus monkeys (13). The marked differences in IgE to Alb and IgG to Alb ratios seen in $\mathrm{S}$ and $\mathrm{RS}$ are consistent with $\operatorname{IgE}$ being a secretory Ig in the lower (subglottic) respiratory tract in rhesus monkeys, an observation suggested for humans by Ishizaka and Newcomb (14). 
TABLE IV

Respiratory Responses of Ascaris $R R$ and NR to Aerosol Challenge with

Different Concentrations of Car

\begin{tabular}{|c|c|c|c|c|c|}
\hline \multirow{2}{*}{$\begin{array}{l}\text { Car used for } \\
\text { challenge }\end{array}$} & \multicolumn{2}{|c|}{$\begin{array}{l}\text { Positive responses } \\
\div \text { challenges at } \\
\text { that concentration }\end{array}$} & \multicolumn{2}{|c|}{$\begin{array}{c}\text { Challenges } \\
\text { with positive } \\
\text { responses }\end{array}$} & \multirow[b]{2}{*}{$P$ values* } \\
\hline & NR & $\mathbf{R} \mathbf{R}$ & NR & $\mathbf{R} \mathbf{R}$ & \\
\hline$m g / m l$ & \multicolumn{5}{|c|}{$\%$} \\
\hline 0.1 & $0 / 8$ & $2 / 10$ & 0 & 20 & $<0.20$ \\
\hline 0.25 & $0 / 8$ & $2 / 10$ & 0 & 20 & $<0.20$ \\
\hline 2.5 & $1 / 8$ & $9 / 10$ & 12.5 & 90 & $<0.001$ \\
\hline 10 & $4 / 6$ & $10 / 10$ & 67 & 100 & $<0.005$ \\
\hline Totals & $5 / 30$ & $23 / 40$ & 17 & 57.5 & $<0.001$ \\
\hline
\end{tabular}

* $P$ values calculated by chi-square.

All monkeys tested by aerosol challenge with Car have a respiratory response simulating an antigen-induced response if the concentration of Car is sufficient. The studies currently reported demonstrate that the $R R$ rhesus monkeys that have consistent responses to aerosol challenge with antigen are, as a group, more reactive to Car. This is demonstrated by the responses of the RR group at lower concentrations of Car (Table IV). The hyperresponsiveness of the human asthmatic to analogues of acetylcholine is well known $(15,16)$, and the current results in the RR group of rhesus monkeys may constitute a related finding in this primate model. Thus, in the rhesus model of asthma we describe here, the

TABLE V

Recent Studies with Rhesus Monkeys with Ascaris-Induced Respiratory Responses that Demonstrate Some Research Applications of a Colony of Asthmatic Monkeys

\begin{tabular}{lc}
\hline \multicolumn{1}{c}{ Study } & Reference \\
\hline $\begin{array}{l}\text { Pulmonary function parameters in rhesus asthma } \\
\text { Demonstration of the mast cells and basophils }\end{array}$ & 6 \\
in the bronchial lumens of primates & 17 \\
$\begin{array}{l}\text { Demonstration that rhesus peripheral blood } \\
\text { leukocytes and free respiratory cells of the mast } \\
\text { cell type release histamine and a slow-reacting } \\
\text { substance of anaphylaxis }\end{array}$ & 10 \\
$\begin{array}{l}\text { Inhibition of respiratory reaction by pharmacologic } \\
\text { agents such as cromolyn sodium and }\end{array}$ & 3 \\
$\begin{array}{l}\text { antihistamine } \\
\text { Effect of cholinergic and anticholinergic agents in } \\
\text { antigen-induced respiratory responses }\end{array}$ & 12 \\
$\begin{array}{l}\text { Arterial and muscle oxygen changes during } \\
\text { rhesus asthma }\end{array}$ & 7 \\
$\begin{array}{l}\text { Development of a double-antigen challenge system } \\
\text { for demonstrations of the effects of pharmacologic } \\
\text { agents on monkey asthma }\end{array}$ & 18 \\
\hline
\end{tabular}

data indicate that the presence of reaginic antibody alone is not sufficient to result in a consistently $R R$ animal. Because the members of $\mathrm{RR}$ group are more reactive to cholinergic stimuli (Car), each animal of the $R R$ group is differentiated from NR by both the presence of reagin and a hyperreactive airway. This presents an obvious analogy to the human extrinsic asthmatic.

Prevous studies of $\mathrm{H}$ release from rhesus $\mathrm{RC}$ did not demonstrate significant potentiation of AA-induced $\mathrm{H}$ release by $\mathrm{D}_{2} \mathrm{O}$ (10). The current studies (Fig. 4) suggest that the $\mathrm{RR}$ group has both $\mathrm{H}$ release from $\mathrm{RC}$ due to AA and potentiation of $\mathrm{H}$ release due to $\mathrm{D}_{2} \mathrm{O}$. The failure to demonstrate this previously was because the majority of cell studies utilized animals with cutaneous but not respiratory responses.

The current studies of the RR and NR group demonstrated that the only differences detectable between the two groups were the Car sensitivity and $\mathrm{H}$ release from $\mathrm{RC}$ due to AA (but not of anti-IgE) of the RR groups. We have previously shown a potentiating relationship between the cholinergic stimulation of Car, the immunologic stimulation of antigen, and the pharmacologic stimulation of $\mathrm{H}$ (12). Although these interactions are complex, study of the autonomic, immunologic, and pharmacologic interactions may help determine why some animals are consistent respiratory responders and others are not.

\section{ACKNOWLEDGMENTS}

We wish to thank Mr. Michael Nolan of Primate Imports for his assistance in obtaining ascaris-sensitive monkeys.

This work was supported by U. S. Public Health Service Grant AI 11759 and the Ernst S. Bazley Grant.

\section{REFERENCES}

1. Patterson, R., and J. F. Kelly. 1974. Animal models of the asthmatic state. Annu. Rev. Med. 25: 53-68. 
2. Hogarth-Scott, R. S. 1967. The molecular weight range of nematode allergens. Immunology. 13: 535-537.

3. Patterson, R., C. H. Talbot, and M. Brandfonbrener. 1971. The use of IgE mediated responses as a pharmacologic test system. The effect of disodium cromoglycate in respiratory and cutaneous reactions and on the electrocardiograms of rhesus monkeys. Int. Arch. Allergy Appl. Immunol. 41 : 592-603.

4. Patterson, R., I. M. Suszko, and K. E. Harris. 1975. Potentiation of IgE-mediated cutaneous reactivity and blood leukocyte histamine release by deuterium oxide. Clin. Exp. Immunol. 19: 335-342.

5. Patterson, R. 1969. Laboratory models of reaginic allergy. Prog. Allergy. 13: 332-407.

6. Kelly, J. F., D. W. Cugell, R. Patterson, and K. E. Harris. 1974. Acute airway obstruction in rhesus monkeys induced by pharmacologic and immunologic stimuli. J. Lab. Clin. Med. 83: 738-749.

7. Patterson, R., and K. E. Harris. 1975. Arterial and muscle oxygen tension in experimental models of asthma in dogs and rhesus monkeys. Int. Arch. Allergy Appl. Immunol. 49: 381-390.

8. Gleich, G. J., A. K. Averbeck, and H. A. Swedlund. 1971. Measurement of $\operatorname{IgE}$ in normal and allergic sera by radioimmunoassay. J. Lab. Clin. Med. 77: 690-698.

9. Ishizaka, K., and T. Ishizaka. 1968. Reversed type allergic skin reactions by anti- $\gamma \mathrm{E}$-globulin antibodies in humans and monkeys. J. Immunol. 100: 554-562.

10. Patterson, R., L. W. Chakrin, I. M. Suszko, J. S. Mengel, and J. E. Wardell, Jr. 1976. IgE mediated release of histamine and a SRS-A from bronchial and peripheral blood leukocytes of rhesus monkeys. J. Lab. Clin. Med. In press.
11. Pruzansky, J. J., and R. Patterson. 1966. Histamine release from leukocytes of hypersensitive individuals. I. Use of several antigens. J. Allergy. 38: 315-320.

12. Patterson, R., and K. E. Harris. 1976. The effect of cholinergic and anticholinergic agents on the antigeninduced airway response in rhesus monkeys. J. Lab. Clin. Med. In press.

13. Reynolds, H. Y., and H. H. Newball. 1974. Analysis of proteins and respiratory cells obtained from human lungs by bronchial lavage. J. Lab. Clin. Med. 84: 559573.

14. Ishizaka, K., and R. W. Newcomb. 1970. Presence of $\gamma E$ in nasal washings and sputum from asthma patients. J. Allergy. 46: 197-204.

15. Itkin, I. H. 1967. Bronchial hypersensitivity to mecholyl and histamine in asthma subjects. J. Allergy. 40: 245256.

16. Felarca, A. B., and I. H. Itkin. 1966. Studies with quantitative-inhalation challenge technique. I. Curve of dose response to acetyl-beta-methacholine on patients with asthma of known and unknown origin, hay fever subjects and nonatopic volunteers. J. Allergy. 37: 223235.

17. Patterson, R., Y. Tomita, S. H. Oh, I. M. Suszko, and J. J. Pruzansky. 1974. Respiratory mast cells and basophiloid cells. I. Evidence that they are secreted into the bronchial lumen, morphology, degranulation and histamine release. Clin. Exp. Immunol. 16: 223-234.

18. Patterson, R., J. S. Irons, and K. E. Harris. 1975. Potentiating effect of $\mathrm{D}_{2} \mathrm{O}$ on the ascaris-induced, reagin-mediated model of asthma in the rhesus monkey studied with a double aerosolized antigen challenge technique. Int. Arch. Allergy Applied Immunol. 48: 412-421. 